\title{
IDENTIFIKASI MOLEKULER BAKTERI DALAM FESES KUCING (Felis domestica) YANG DITUMBUHKAN PADA DE MANN ROGOSA SHARPE AGAR (MRSA)
}

\author{
MOLECULAR IDENTIFICATION OF BACTERIA IN CAT (Felis \\ domestica) FECES GROWN ON DE MANN ROGOSA SHARPE AGAR \\ (MRSA)
}

\author{
Pingkan Stela Mende ${ }^{1)}$, Johanis Pelealu ${ }^{1)}$, Beivy Kolondam ${ }^{1)}$ \\ ${ }^{1)}$ Jurusan Biologi, FMIPA Unsrat Manado, 95115
}

\begin{abstract}
Bacteria has many important role in the digestive tract of animals. Beneficial bacteria in the digestive tract are thought to be able to inhibit the growth of pathogenic bacteria, while pathogenic bacteria can cause diseases and infections. This research aimed to grow bacteria living in cat feces and to identify it with molecular method. This study used moleculer identification based on I6S rRNA gene as marker. There were three isolate if bacteria taken from the culture. Two isolates were identified as Enterococcus faecalis (with $99 \%$ and $100 \%$ in similarity compared with GenBank database). One isolate was identified as Kurthia gibsonii (100\% in similarity).
\end{abstract}

Keywords: Bacteria, cat feces, MRS Agar, gen 16s rRNA

\begin{abstract}
ABSTRAK
Bakteri memiliki peran penting dalam saluran pencernaan hewan. Bakteri yang menguntungkan dalam saluran pencernaan dianggap mampu menghambat pertumbuhan bakteri patogen, sedangkan bakteri yang merugikan dalam saluran pencernaan hewan dianggap mampu menyebabkan penyakit dan infeksi. Penelitian ini bertujuan untuk menumbuhkan bakteri-bakteri yang ada dalam feses kucing dan mengidentifikasikannya dengan metode molekuler. Penelitian ini menggunakan identifikasi molekuler berdasarkan gen 16S rRNA sebagai penanda. Hasil penelitian ini mendapatkan tiga isolat bakteri. Dua diantaranya teridentifikasi sebagai Enterococcus faecalis (kemiripan 99\% dan 100\% dengan yang ada di GenBank). Satu isolat teridentifikasi sebagai Kurthia gibsonii (kemiripan 100\%).
\end{abstract}

Kata kunci: Bakteri, feses kucing, Agar MRS, gen 16S rRNA 


\section{PENDAHULUAN}

Bakteri merupakan organisme yang jumlahnya paling banyak di bumi, umumnya bersel satu, tidak memiliki membran inti sel, berukuran sangat kecil, serta memiliki peran besar di bumi. . Secara umum, bakteri dapat dijumpai di berbagai habitat yang cukup luas, salah satunya dalam saluran pencernaan manusia dan hewan (Misgiyarti et al., 2002). Berdasarkan peranannya, bakteri terbagi atas dua macam, yaitu bakteri yang merugikan dan bakteri yang menguntungkan. Bakteri yang menguntungkan dalam saluran pencernaan dianggap memiliki peran penting dalam saluran pencernaan karena dapat memberikan manfaat dalam meningkatkan kesehatan dan daya imunitas hewan (Ziemer dan Gibson, 1998), dapat mencegah infeksi saluran cerna (Saranraj et al., 2013), dan dapat menghambat pertumbuhan bakteri patogen dalam saluran pencernaan manusia dan hewan (Savadogo et al., 2004).

Bakteri yang merugikan dianggap mampu menyebabkan penyakit dan infeksi saluran pencernaan. Beberapa penelitian telah dilakukan untuk mengeksplorasi jenis-jenis bakteri yang ada dalam saluran pencernaan hewan, tetapi belum ada penelitian tentang jenis-jenis bakteribakteri yang terdapat dalam saluran pencernaan kucing liar, terutama yang ada di Indonesia.

Untuk mengetahui jenis-jenis bakteri yang ada dalam saluran pencernaan perlu adanya media. Media adalah suatu bahan yang terdiri dari campuran zat-zat dan nutrisi yang diperlukan mikroba untuk pertumbuhannya, untuk tujuan-tujuan seperti isolasi, seleksi dan diferensiasi biakan yang didapat (Antonita, 2010). Berdasarkan sifat-sifatnya, media terbagi atas beberapa macam media salah satunya media umum dan media selektif (Dwidjoseputro, 1994). MRSA merupakan media selektif yang diperkenalkan oleh De Mann, Rogosa, dan Sharpe tahun 1960 untuk memperkaya, menumbuhkan dan mengisolasi jenis bakteri asam laktat dari seluruh jenis bahan. Di lain sisi, MRS agar tidak cukup selektif, karena ada kemungkinan jenis bakteri lain dapat tumbuh dalam media tersebut.

Penelitian ini bertujuan untuk menumbuhkan bakteri dalam feses kucing pada media MRSA. Bakteri-bakteri yang tumbuh dapa media MRSA akan diidentifikasi menggunakan teknik molekuler berdasarkan sekuens gen 16S rRNA.

\section{METODE PENELITIAN}

\section{Preparasi Sampel}

Penelitian ini dimulai dengan pengambilan sampel. Sampel feses kucing jantan yang berumur 2 tahun 4 bulan diambil menggunakan sendok steril dan ditampung di botol kaca steril dengan menambahkan $5 \mathrm{~mL}$ aquades. Setelah itu mulut botol ditutup menggunakan aluminium foil kemudian dibawa ke laboratorium.

\section{Isolasi Bakteri}

Sebanyak $5 \mathrm{mg}$ feces kucing yang telah dicampurkan aquades yang mengandung bakteri dipindahkan ke dalam tabung reaksi dengan menambahkan $10 \mathrm{ml}$ aquades dan di homogenkan. Sebanyak 1 $\mathrm{ml}$ sampel dipipet ke dalam tabung reaksi yang baru dengan menambahkan $9 \mathrm{ml}$ 
aquades (pengenceran $10^{-1}$ ), lakukan pengenceran ini dengan cara yang sama sampai ke (Pengenceran ke $10^{-5}$ ) untuk memperkecil atau mengurangi jumlah mikroba (Wasteson et al., 2009). Sebanyak $1 \mathrm{ml}$ sampel dari masing-masing tabung reaksi dipindahkan dengan pipet ke dalam cawan petri yang berisi agar MRS, selanjutnya diinkubasikan selama 48 jam dengan suhu $37^{\circ} \mathrm{C}$ (Lawalata et al., 2011). Diambil tiga koloni bakteri untuk dimurnikan pada agar MRS yang baru dengan metode Streak plate. Setelah itu, bakteri tunggal dipindahkan ke agar MRS miring untuk ditumbuhkan.

\section{Ekstraksi DNA dan Amplifikasikan Gen 16S rRNA}

Ekstraksi DNA bakteri dilakukan menggunakan Plant Genomic DNA mini kit (Geneaid). Amplifikasi gen 16S rRNA menggunakan kit My Taq HS Red Mix (Bioline). Primer yang digunakan yaitu BKXF (forward) dan BKXR (reverse) (Kolondam 2018, komunikasi pribadi). Sebelum memulai proses amplifikasi terlebih dahulu membuat Mastermix dengan komposisi MyTaq $20 \mu \mathrm{L}$, DNA 2 $\mu \mathrm{L}$, primer forward dan reverse masingmasing $1,5 \mu \mathrm{L}$ dan miliQ water $15 \mu \mathrm{L}$ total reaksinya sebesar $40 \mu \mathrm{L}$. Pengaturan suhu untuk PCR: denaturasi awal pada suhu $95^{\circ} \mathrm{C}$ selama 3 menit, kemudian dilanjutkan dengan 35 siklus denaturasi

Tabel 1. Hasil Pengamatan morfologi koloni bakteri dari feses kucing pada media MRSA

\begin{tabular}{|c|c|c|c|c|}
\hline \multirow{2}{*}{ Isolat Bakteri } & \multicolumn{4}{|c|}{ Morfologi Koloni } \\
\cline { 2 - 5 } & Warna & Tepi & Bentuk & Bentuk Permukaan \\
\hline PSM1 & Putih Susu & Bergerigi & Bulat & Cembung \\
\hline PSM2 & Putih Krem & Rata & Bulat & Cembung \\
\hline
\end{tabular}

pada suhu $95^{\circ} \mathrm{C}$ selama 30 detik, penempelan primer pada suhu $55^{\circ} \mathrm{C}$ selama 30 detik, elongasi pada suhu $72^{\circ} \mathrm{C}$ selama 50 detik dan tahap terakhir yaitu polimerisasi pada suhu $72^{\circ} \mathrm{C}$ selama 1 menit. Fragmen DNA yang telah diamplifikasi beserta dengan primer dikirim ke First Base C.O Malaysia untuk di sekuensing.

\section{Analisis Data}

Analisis data hasil sekuensing dianalisis dengan menggunakan software Geneious V.5.6. Sekuens DNA dianalisis menggunakan software Basi Local Alignment Search Tool (BLAST) pada situs (http://blast.ncbi.nlm.nih.gov) untuk mencari sekuens yang serupa yang tersedia di GenBank.

\section{HASIL DAN PEMBAHASAN}

Pengamatan Morfologi Koloni

Bakteri diisolasi dari sampel feses kucing dengan menggunakan metode pengenceran berseri. Dari hasil pengenceran, setelah diamati ada tiga isolat dengan morfologi koloni yang berbeda. Isolat tersebut terdapat pada pengenceran $10^{-3}$ sampai $10^{-5}$ yang kemudian diberi nama PSM1, PSM2 dan PSM3 (Gambar 1). Morfologi koloni dapat dilihat dalam (Tabel 1). 


\begin{tabular}{|l|l|l|l|l|}
\hline PSM3 & Putih bening & Bergerigi & Bulat & Cembung \\
\hline
\end{tabular}
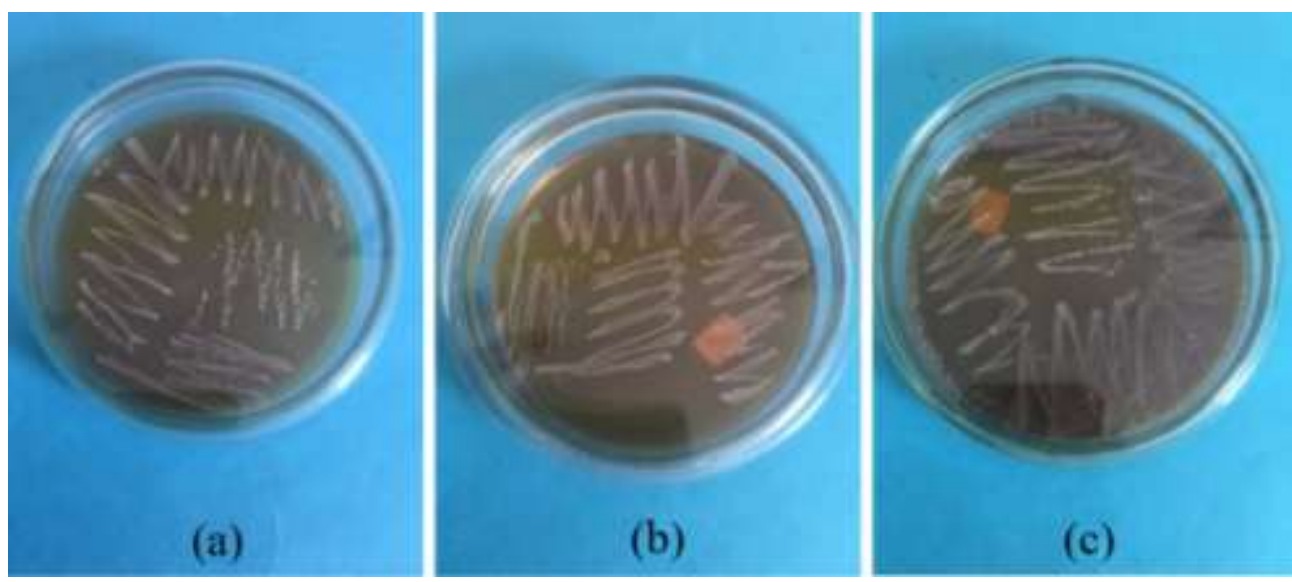

Gambar 1. Isolat hasil pemurnian bakteri: (a) PSM1 (b) PSM2 (c) PSM3

\section{Identifikasi Bakteri Menggunakan Gen Penanda 16S rRNA}

Berdasarkan hasil elektroforesis fragmen DNA bakteri yang telah diamplifikasikan dengan gen $16 \mathrm{~S}$ rRNA, dapat diketahui bahwa panjang fragmen DNA berada pada kisaran 100-1100 bp (Gambar 2). Dari hasil sekuensing, dicari sekuens-sekuens gen 16S rRNA yang mirip dengan sekuens PSM1, PSM2 dan PSM3 dengan menggunakan BLAST (Basic Local Alignment Search Tool). Dari hasil pencarian ini diketahui PSM1 memiliki kemiripan $99 \%$ dengan Enterococcus faecalis (nomor aksesi: MH819482.1), PSM2 memiliki kemiripan $100 \%$ dengan E. faecalis (nomor aksesi: MH779826.1), dan PSM3 memiliki kemiripan $100 \%$ dengan Kurthia gibsonii (nomor aksesi: MH619509.1). Dua dari tiga bakteri ini merupakan bakteri yang berjenis sama berdasarkan data di GenBank. 


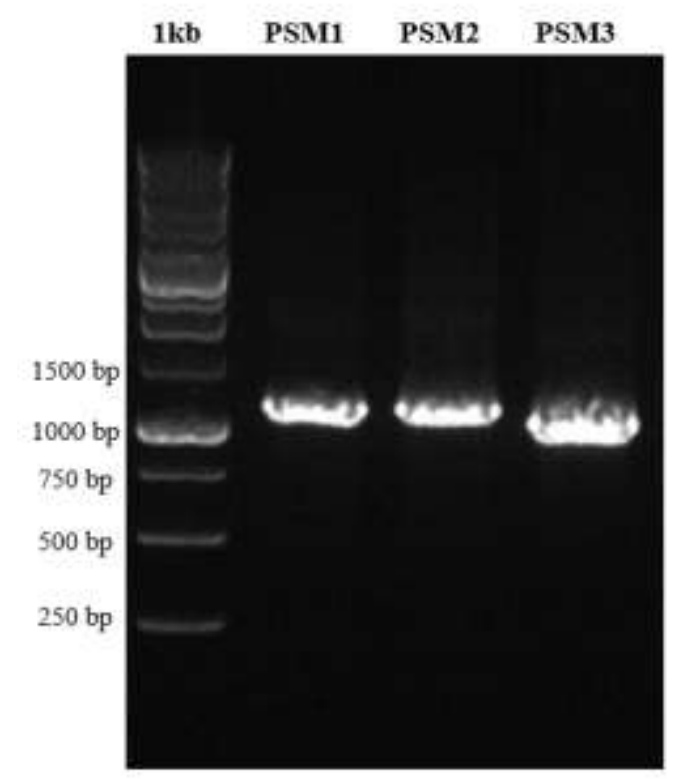

Gambar 2. Visualisasi hasil amplifikasi gen $16 \mathrm{~S}$ rRNA sampel bakteri dalam elektroforesis gel agarosa $0.8 \%$

PSM1 dan PSM2 memiliki koloni yang berbeda tetapi diidentifikasi menghasilkan jenis yang sama yaitu E. faecalis. Perbedaan morfologi koloni diduga karena adanya variasi koloni pada saat pertumbuhan E. faecalis. Variasi koloni juga terjadi sesuai dengan yang digambarkan oleh penelitian Proctor et al. (2006). Penelitian ini membahas tentang variasi koloni, yakni populasi koloni yang berkembang lambat dengan karakter fenotip yang khas. Ditemukan variasi berupa ukuran koloni, tingkat pertumbuhan dan morfologi koloni yang atipikal pada $E$. faecalis.

\section{Deskripsi Bakteri Yang Tumbuh Pada Media MRSA}

E. faecalis merupakan bakteri Gram positif, tidak membentuk spora, fakultatif anaerob, kokus, dan tidak menghasilkan reaksi katalase dengan hidrogen peroksida (Rollins et al., 2009). Bakteri ini bersifat homofermentatif yang mengubah glukosa menjadi asam laktat (de Vos et al., 2009). Selain hidup dalam dalam saluran pencernaan manusia dan hewan, E. faecalis juga dapat dijumpai dalam saluran kemih dan dapat juga berkoloni dalam rongga mulut manusia. Secara filogenetik, Enterococcus termasuk dalam Divisi Firmicitus, Ordo Lactobacillales dan famili Enterococcaceae (Dian, 2005).

Kurthia gibsonii merupakan bakteri Gram positif, tidak berspora dan berbentuk batang (Kediie, 1991). Selain hidup dalam saluran pencernaan hewan, bakteri ini juga dapat ditemui di lingkungan dengan bahan organik yang membusuk seperti bangkai babi (Shaw and Keddie, 1993), kotoran hewan ternak, dan makanan lainnya (Pin and Baranyi, 1998). Pada penelitian sebelumnya juga menunjukan bahwa $K$. gibsonii juga telah berhasil diisolasi dari feses orang dewasa yang mengalami diare akut. Genus Kurthia tidak dianggap sebagai bakteri patogen. Kurthia termasuk dalam divisi Firmicitus, ordo Bacillales dan famili Planococcaceae (Shaw dan Keddie, 1993). 


\section{KESIMPULAN}

Bakteri hasil isolasi dari feses kucing yang tumbuh pada media MRSA yang diidentifikasi secara molekuler menunjukkan sampel PSM1 memiliki kemiripan 99\% dengan Enterococcus faecalis (MH819482.1), PSM2 memiliki kemiripan $100 \%$ dengan Enterococcus faecalis (MH779826.1) dan PSM3 memiliki kemiripan 100\% dengan Kurthia gibsonii (MH619509.1).

\section{DAFTAR PUSTAKA}

Dwidjoseputro. 1990. Dasar-Dasar Mikrobiologi. Jakarta: Djambatan.

Keddie, RM. 1981. The Prokaryotes: A Handbook tentang Habitat, Isolasi dan Identifikasi Bakteri (1 ed.). Springer-Verlag Berlin Heidelberg.

Lawalata, H.J., Sembiring, L., and Rahayu, E.S. 2011. Moleculer Identification of Lactid Acid Bacteria Producing Antimicrobial Agents from Bakasang, An Indonesian Traditional Fermented Fish Product. Indonesian Journal of Biotechnology. 16 (2): 93-99.

Misgiyarta dan Widowati. 2005. Seleksi dan Karakterisasi Bakteri Asam Laktat (BAL) Indigenus. Balai Besar Penelitian dan Pengembangan Pascapanen Pertanian, Bogor.

Pin C, Baranyi J. 1998. Predictive models as means to quantify the interactions of spoilage organisms. Int J Food Microbiol. 41:59-72.

Proctor, R. A., C. von Eiff, B. C. Kahl, K. Becker, P. McNamara, M. Herrmann, and G. Peters. 2006. Small colony variants: a pathogenic form of bacteria that facilitates persistent and recurrent infections. Nat. Rev. Microbiol. 4295-305.

Rollins, D. M. dan Joseph, S. W., 2000, Enterococcus

Summary, Pathogenic Microbiology, J Microbiol. 2:13-28

Salvadogo, A. 2006. Bacteriocins and Lactic Acid Bacteria-a miniriview. African Journal of Biotechnology 5(9):678-683.

Shaw, S. and Keddie, R. M.1983. A numerical taxonomic study of the genus Kurthia with revised description of Kurthia zopfi and a description of Kurthia gibsonii sp. nov. Systematic and Applied Microbiology 4, 253-276.

Wasteson, Y, and Hornes, E. 2009. Pathogenic Escherichia Coli Found in Food. International Journal of Food Microbiology 12: 103-114

Ziemer, C.J., and Gibson, G.R (1998). An Overview of Probiotic, Prebiotics and Synbiotic in Functional Food Concept: Perspectives and Future Strategies. International Dairy Journal. 8:473-479. 